\title{
КЛІНІЧНИЙ ПОРТРЕТ ДІВЧИНКИ ПУБЕРТАТНОГО ВІКУ З НЕАЛКОГОЛЬНОЮ ЖИРОВОЮ ХВОРОБОЮ ПЕЧІНКИ ТА МЕТАБОЛІЧНО НЕЗДОРОВИМ ОЖИРІННЯМ
}

\section{๑Е. Ф. Чайківська \\ Львівський національний медичний університет імені Данила Галицького}

PЕЗЮМЕ. В Україні 10 \% дитячого населення має надлишкову масу тіла. Одним із сучасних актуальних питань пубертатного періоду у дівчат з ожирінням $є$ дифузні захворювання печінки, з яких неалкогольна жирова хвороба печінки (НАЖХП) є однією з найчастіших проблем зі здоров'ям.

Мета - вивчення особливостей клініко-метаболічних показників та статевого розвитку дівчаток пубертатного віку з НАЖХП та з метаболічно нездоровим ожирінням.

Матеріал і методи. Під спостереженням перебували 120 дівчат у віці 12-17 років з НАЖХП та з метаболічно нездоровим ожирінням, а також 180 умовно соматично здорових дівчат з нормальним статевим розвитком і 3 нормальною масою тіла. Вивчали антропометричні показники, параметри ферментного, ліпідного, вуглеводного, пуринового обміну, секрецію адипоцитокінів, 25(OH)D, оцінювали статевий розвиток.

Результати. Для дівчаток пубертатного віку з НАЖХП та ожирінням були найхарактерніші збільшення індексу маси тіла у 2,80 раза ( $<<0,01)$, в основному за рахунок збільшення індексу жирової тканини в 3,07 раза ( $p<0,01)$, співвідношення окружності талії/окружності стегон в 1,26 раза ( $<<0,01)$. Рівень лептину вірогідно перевищував аналогічний показник групи контролю в 14,58 раза, АЛТ - в 2,17, глюкози - в 1,25, С-пептиду - в 1,77, індекс НОМАв 1,90, сечової кислоти - в 2,27, а $25(\mathrm{OH})$ D був знижений у 1,34 раза (р<0,01). Дівчата з НАЖХП характеризувалися більш раннім настанням менархе - $(11,45 \pm 0,03)$ проти $(12,43 \pm 0,04)$ років у контролі, вищим балом статевого розвитку за Л. Г. Тумилович - $(10,89 \pm 0,16)$ проти $(10,27 \pm 0,18)$ балів, порушеннями менструальної функції з наявністю у 62,50 \% випадків олігоменореї, у 27,50 \% - аменореї, у 10,00 \% - рясних менструацій, у 14,17 \% - дисменореї.

Висновки. Клінічний портрет дівчинки пубертатного віку з НАЖХП та метаболічно нездоровим ожирінням характеризується порушеннями ліпідного, вуглеводного, пуринового обміну, секреції адипоцитокінів, недостатністю або дефіцитом вітаміну D і більш раннім статевим дозріванням, прискореним адренархе, інвертованим пубертатом, порушеннями становлення менструальної функції.

КлючОВІ СлОВА: ожиріння; неалкогольна жирова хвороба печінки; композиція тіла; метаболічний синдром; ферменти печінки; ліпідний обмін; вуглеводний обмін; пуриновий обмін; 25(ОН)D; статевий розвиток.

Вступ. Пубертатний період $є$ унікальною природною потужною функціональною навантажувальною пробою. На етапі ростового стрибка вперше починають проявлятися та маніфестувати раніше приховані дефекти та захворювання. З'являються і нові, типові для періоду статевого дозрівання, морфофункціональні розлади. В Україні 10 \% дитячого населення має надлишкову масу тіла, що $є$ надзвичайно актуальною проблемою. У структурі хвороб ендокринної системи серед дітей та підлітків нашої країни ожиріння становить 11,1 \%. Щорічно воно фіксується в 1820 тис. дітей віком до 17 років $[1,2]$. Одним із сучасних актуальних проблемних питань пубертатного періоду в дівчат з ожирінням $\epsilon$ дифузні захворювання печінки, в тому числі неалкогольна жирова хвороба печінки (НАЖХП) [16]. У 23-53 \% випадків розвиток НАЖХП у дітей пов'язаний з надмірною масою тіла або ожирінням і останніми роками розглядається як компонент метаболічного синдрому, складовими якого є ожиріння, дисліпідемія та гіпертензія [3].

Стеатоз печінки - це клінічний стан, що характеризується інфільтрацією жиру більш ніж у $5 \%$ гепатоцитів при біопсії печінки, що не пов'язано з надмірним вживанням алкоголю, автоімунним за- хворюванням, вірусними інфекціями або застосуванням стеатогенних препаратів [4, 9]. НАЖХП охоплює спектр гістологічних змін печінки, від стеатозу печінки до неалкогольного стеатогепатиту, фіброзу, цирозу, кінцевої стадії захворювання печінки і гепатоцелюлярної карциноми [14]. Наявні дані переконливо свідчать про те, що захворюваність НАЖХП поширюється за межі печінки і пов'язана з основними компонентами метаболічного синдрому вже в педіатричному віці $[8,10]$.

Метаболічний синдром був уперше описаний в 1988 р. [18] й визначений як сукупність метаболічних порушень і факторів ризику серцево-судинних захворювань. Хоча метаболічний синдром отримав кілька визначень в педіатричній популяції, існує згода щодо того, що центральне ожиріння, порушення толерантності до глюкози, дисліпідемія і гіпертензія $\epsilon$ його істотними ознаками [13] i, що важливо, НАЖХП $є$ печінковим проявом цього дисметаболічного стану [12].

Впродовж останніх 20 років поширеність НАЖХП у дітей зросла більш ніж удвічі. Це зростання частково пояснюється значним внеском зростання ожиріння у дітей, що робить НАЖХП найчастішою причиною захворювань печінки. У США 7 мільйонів дітей і підлітків страждають на 
Огляди літератури, оригінальні дослідження, погляд на проблему, випадок з практики, короткі повідомлення стеатоз печінки [15] з поширеністю 3-10\% серед населення США [7]. В Європі були зареєстровані різні дані про поширеність НАЖХП: від 2,5 \% у Великобританії [11] до 12,5 \% в Італії [5].

Відомо, що наявність НАЖХП збільшується зі збільшенням категорії індексу маси тіла (IMT). В автопсійному дослідженні, проведеному в Каліфорнії, поширеність гістологічно підтвердженої НАЖХП склала 38 \% у дітей з ожирінням [15]. Відповідно, у великому автопсійному дослідженні на рівні спільноти поширеність жирової хвороби печінки у дітей з ожирінням склала 26 \% [17]. Крім того, в недавньому систематичному огляді E. L. Anderson et al. (2015) [19] було повідомлено про поширеність дитячої НАЖХП від $8 \%$ у дітей без ожиріння до 34 \% у дітей з ожирінням. Інсулінорезистентніть $\epsilon$ найважливішим фактором, що пов'язує НАЖХП і метаболічний синдром у дітей та підлітків з ожирінням [6]. Інсулінорезистентніть і метаболічний синдром можуть бути єдиними проявами і провісниками гіперандрогенії, які можуть змінювати становлення статевого розвитку і призвести до порушень менструальної і овуляторної функцій.

Мета - вивчення особливостей клініко-метаболічних показників та статевого розвитку дівчаток пубертатного віку з НАЖХП та з метаболічно нездоровим ожирінням.

Матеріал і методи дослідження. Під спостереженням перебували 120 дівчат у віці 12-17 років з неалкогольною жировою хворобою печінки групи НАЖХП і з метаболічно нездоровим ожирінням, а також 180 умовно соматично здорових дівчат з нормальним статевим розвитком групи $\mathrm{K}$ і з нормальною масою тіла. Серед обстежених пацієнток групи НАЖХП 68 (56,67 \%) дівчаток мали андроїдний тип ожиріння з переважним відкладанням жиру у верхній частині тулуба (синоніми: абдомінальний, вісцеральний, центральний, верхній тип ожиріння, ожиріння за типом «яблука») (група А), 52 (43,33 \%) - гіноїдний тип ожиріння $з$ переважним відкладанням жиру в нижній частині тулуба (синоніми: глютеофеморальний, сіднично-стегновий, нижній тип ожиріння, ожиріння за типом «груші») (група Г). Критеріями виключення з групи НАЖХП були вік молодше за 12 або старше за 17 років; вибуття з-під спостереження; неповне медичне обстеження, антропометричне вимірювання або лабораторні дані; гепатит B (HBV), гепатит C (HCV) або обидва; автоімунний гепатит; хвороба Вільсона; прийом гепатотоксичних та стеатогенних препаратів; попередні операції на печінці та жовчовивідних шляхах; звичне вживання алкоголю; цироз печінки, вузлики або пухлини, виявлені при ультразвуковому скануванні.

Комплекс обстеження включав клініко-анамнестичні дані, антропометрію, клінічний аналіз крові, загальний аналіз сечі, копрограму, паразитологічне дослідження калу, електрокардіографію, дослідження ліпідограми, ліпопротеїдів низької (ЛПНЩ) та високої (ЛПВЩ) щільності, рівня глюкози, інсуліну, визначення НОМА-індексу, С-пептиду, тригліцеридів, загального холестерину, сечової кислоти, лептину і адипонектину, аланінамінотрасферази (АЛТ), аспартатамінотрасферази (АСТ), $\mathrm{v}$-глютамілтранспептидази ( го білка, амілази, аналіз крові на маркери гепатитів B, C (HBsAg, анти-HBC IgG, анти-HCV IgG сумарний, анти-HCV IgG до сог-антигену), автоімунологічні дослідження (антинуклеарні антитіла - ANA, антигладеньком'зові антитіла - SMA, антитіла до мікросом печінки та нирок - LKM 1), ультразвукове дослідження (УЗД) та еластографію органів гепатобіліарної системи за стандартними методиками, консультацію ендокринолога, гастроентеролога, за показаннями - кардіолога, пульмонолога, алерголога та інших фахівців. Спеціальний комплекс діагностичних методів включав панель неінвазивних методів оцінки стану печінки - тест ФіброМакс, ФіброТест, Гено ФіброТест.

Антропометричне обстеження включало вимірювання зросту; визначення маси тіла і розрахунок показника IMT за формулою [вага (кг)/ зріст $\left.\left(\mathrm{M}^{2}\right)\right]$. IMT оцінювали за стандартами ВООЗ, 3 оцінкою стандартного відхилення SDS, якщо співвідношення «ІМТ/вік» перевищувало медіанне значення, вказане в Стандартних показниках фізичного розвитку дітей (ВООЗ), більше ніж на два SDS. Вимірювання окружності талії (ОT) проводили стійкою до розтягування сантиметровою стрічкою в середній точці між нижнім краєм останнього ребра і верхньої частини гребеня клубової кістки, відповідно до рекомендацій ВООЗ. Вимірювання окружності стегон (ОС) проводили стійкою до розтягування сантиметровою стрічкою навколо найширшої частини сідниць, утримуючи стрічку паралельно до підлоги, також відповідно до рекомендацій ВООЗ. Проведена оцінка кількості й розподілу жирової тканини в організмі методом двоенергетичної рентгенівської абсорбціометрії з використанням апарату Lunar Prodigy (США) в режимі сканування всього тіла (Total Body Composition, променеве навантаження 0,0003 мГрей). Досліджено загальний вміст жиру в організмі, відсотковий вміст андроїдного і гіноїдного жиру та їх співвідношення, відсотковий вміст всієї жирової, безжирової та кісткової тканин. На підставі даних загальної кількості жиру був проведений розрахунок індексу маси жиру (ІМЖ) за формулою: [загальна кількість жирової тканини $\left(\right.$ Кг)/зріст $\left.\left(\mathrm{M}^{2}\right)\right]$. 
Огляди літератури, оригінальні дослідження, погляд на проблему, випадок з практики, короткі повідомлення

Рівень 25(OH)D у венозній крові визначали методом імуноферментного аналізу за допомогою тест систем і аналізатора EUROIMMUN (Hiмеччина) згідно з інструкціями виробника. Оцінювали результати за рекомендаціями Міжнародного товариства ендокринологів: нормальний вміст вітаміну D - 30-100 нг/мл (76-250 нмоль/мл) 25(OH)D, нестача вітаміну D - вміст 25(OH)D 2129 нг/ мл (51-75 нмоль/л), дефіцит вітаміну D вміст 25(OH)D менше від 20 нг/мл (менше від 50 нмоль/л).

Статевий розвиток дівчат пубертатного віку аналізували за J. М. Tanner (1962) та Л. Г. Тумилович і співавт. (1975).

Статистичний аналіз результатів проводили за допомогою програми Microsoft Excel 2010. Для оцінки нормальності розподілу вибірок оцінювали критерій Колмогорова - Смирнова, критерій Шапіро - Уілка, показники асиметрії та ексцесу, а також медіану і середнє значення показника. Якщо рівні значимості критерію Колмогорова - Смирнова і критерію Шапіро - Уілка були вище 5 \% (р>0,05), показники асиметрії і ексцесу виявлялися в діапазоні від -1 до +1, а медіана і середнє істотно не відрізнялися один від одного, то нульова гіпотеза (Н0) приймалася і розподіл вибірки оцінювали як нормальний. При недотриманні вказаних умов приймали альтернативну гіпотезу $(\mathrm{H} 1)$ і розподіл у вибірці вважали відмінним від нормального. Кількісні змінні описані за допомогою середнього значення (М), похибки стандартного відхилення (SE), а їх порівняння - з використанням t-критерію Стьюдента. Для порівняння розподілу якісних ознак використовували $\chi^{2}$ критерій з поправкою Фішера. При порівнянні змінних в незалежних вибірках застосовувалися U-критерій Манна - Уїтні, для залежних вибірок використовували критерій Вілкоксона. Зв'язок кількісних змінних оцінювали за допомогою коефіцієнта рангової кореляції Спірмена. Для оцінки рівня кореляції використовували шкалу Чеддока.

Результати й обговорення. ПацієНтки з НАЖХП у пубертатному періоді з надмірною масою тіла та ожирінням з однаковою частотою у вікових групах скаржилися на головний біль (55,83 \% (67)), втом- люваність $(59,17 \%(71))$, на збільшення маси тіла (100\%). Скарги на підвищення апетиту (гіперфагію) були у 35,83 \% (43) пацієнток. Білі стрії діагностовані у всіх обстежуваних з НАЖХП, бордового кольору - у 74,17 \% (89) дівчаток-підлітків. Акне реєстрували у 51,67 \% (62) дівчаток-підлітків 3 НАЖХП.

При фізикальному обстеженні у дівчаток групи НАЖХП зазвичай спостерігали надлишковий розвиток підшкірної жирової клітковини, рідше гепатомегалію. Пальпаторно визначалася гладка і рівна поверхня печінки, нижня ії̈ межа при перкусії виступала на 1-3 см нижче краю правої реберної дуги, край був дещо ущільнений, іноді болючий при пальпації. У ряді випадків реєстрували позитивний симптом Ортнера, чутливість у пілородуоденальній зоні, точці Мейо - Робсона, що вказувало на втягнення в патологічний процес жовчного міхура, шлунка, дванадцятипалої кишки, підшлункової залози. У деяких дітей були нестійкі випорожнення. Жовтяниця, як правило, не спостерігалася. Найчастіше діти потрапляли в поле зору лікаря при проведенні УзД органів черевної порожнини з приводу абдомінального больового синдрому, обумовленого дисфункцією біліарного тракту, змінами підшлункової залози, наявністю гастродуоденіту. За даними УЗД, зміни печінки за типом стеатозу у вигляді дифузної дрібновогнищевої неоднорідності, гіперехогенності її паренхіми, а також поглинання ультразвуку на 1/5-1/6 в дистальних відділах паренхіми відзначалися у всіх (100\%) дітей з НАЖХП. Крім того, у 87,50 \% (105) пацієнток також виявлялося збільшення ехогенності підшлункової залози (при цьому було відсутнє підвищення сироваткових рівнів панкреатичної фракції амілази і ліпази).

Середній IMT дівчаток групи НАЖХП перевищував аналогічний у групі К у всіх вікових категоріях, в загальній групі дорівнював $(55,43 \pm 0,69)$ кг/м² i перевищував такий в групі К $((19,58 \pm 0,13)$ кг/м²) у $2,80$ раза ( $<<0,01)$. У пацієнток з андроїдним типом ожиріння ІМТ був більший, ніж у осіб з гіноїдним типом ожиріння, у всіх вікових групах, у середньому у групі А складав $(31,18 \pm 0,30)$ кг/м² проти $(29,31 \pm 0,23)$ кг/м²у групі Г, р<0,01 (табл. 1).

Таблиця 1. Індекс маси тіла в обстежених дівчат залежно від віку, кг/м²

\begin{tabular}{|c|c|c|c|c|}
\hline \multirow{2}{*}{ Вік, роки } & \multicolumn{4}{|c|}{ Група } \\
\hline & НАЖХП & A & $\Gamma$ & $K$ \\
\hline 12 & $27,44 \pm 0,40^{\mathrm{k}}$ & $28,34 \pm 0,38^{\mathrm{k}, \mathrm{r}}$ & $26,10 \pm 0,15^{\mathrm{k}, \mathrm{a}}$ & $17,32 \pm 0,32$ \\
\hline 13 & $28,67 \pm 0,25^{\mathrm{k}}$ & $28,91 \pm 0,31^{\mathrm{k}, \mathrm{r}}$ & $28,43 \pm 0,18^{\mathrm{k}, \mathrm{a}}$ & $19,34 \pm 0,15$ \\
\hline 14 & $28,39 \pm 0,21^{\mathrm{K}}$ & $28,90 \pm 0,18^{\mathrm{k}, \mathrm{r}}$ & $27,62 \pm 0,09^{\kappa, a}$ & $19,63 \pm 0,20$ \\
\hline 15 & $31,32 \pm 0,20^{k}$ & $31,64 \pm 0,12^{k, r}$ & $30,72 \pm 0,26^{k, a}$ & $20,53 \pm 0,17$ \\
\hline 16 & $31,78 \pm 0,71^{\mathrm{k}}$ & $33,41 \pm 0,64^{\mathrm{k}, \mathrm{r}}$ & $29,78 \pm 0,51^{\text {к,a }}$ & $20,31 \pm 0,23$ \\
\hline 17 & $34,60 \pm 0,60^{k}$ & $36,54 \pm 0,40^{\mathrm{k}, \mathrm{r}}$ & $32,67 \pm 0,41^{\mathrm{k}, \mathrm{a}}$ & $20,36 \pm 0,30$ \\
\hline $12-17$ & $30,37 \pm 0,28^{k}$ & $31,18 \pm 0,30^{\mathrm{k}, \mathrm{r}}$ & $29,31 \pm 0,23^{\mathrm{k}, a}$ & $19,58 \pm 0,13$ \\
\hline
\end{tabular}

Примітка. К, а, г- статистично значима різниця з показником груп $\mathrm{K}, \mathrm{A}, \Gamma(\mathrm{p}<0,05)$. 
Огляди літератури, оригінальні дослідження, погляд на проблему, випадок з практики, короткі повідомлення

Співвідношення ОТ/ОС у дівчаток групи НАЖХП було більше за аналогічне в групі К у всіх вікових категоріях, у загальній групі складало

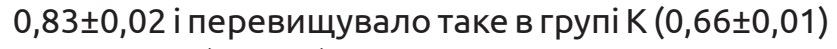
у 1,26 раза ( $<0,01)$. У пацієнток з андроїдним типом ожиріння співвідношення ОТ/ОС було більшим, ніж у дівчаток з гіноїдним типом ожиріння, у всіх вікових групах (табл. 2), у середньому у групі

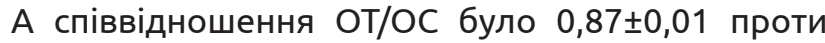

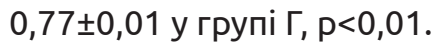

Таблиця 2. Співвідношення окружності талії/окружності стегон у обстежених дівчат залежно від віку, кг/м²

\begin{tabular}{|c|c|c|c|c|}
\hline \multirow{2}{*}{ Вік, роки } & \multicolumn{4}{|c|}{ Група } \\
\hline & НАЖХП & $\mathrm{A}$ & $\Gamma$ & $\mathrm{K}$ \\
\hline 12 & $0,82 \pm 0,01^{\text {k }}$ & $0,85 \pm 0,01^{\mathrm{k}, \mathrm{r}}$ & $0,78 \pm 0,01^{k, a}$ & $0,65 \pm 0,01$ \\
\hline 13 & $0,81 \pm 0,01^{\text {k }}$ & $0,85 \pm 0,01^{\mathrm{k}, \mathrm{r}}$ & $0,78 \pm 0,01^{k, a}$ & $0,65 \pm 0,01$ \\
\hline 14 & $0,81 \pm 0,01^{\text {k }}$ & $0,83 \pm 0,01^{\mathrm{k}, \mathrm{r}}$ & $0,77 \pm 0,01$ k,a & $0,65 \pm 0,01$ \\
\hline 15 & $0,84 \pm 0,01^{\text {k }}$ & $0,88 \pm 0,01^{\mathrm{k}, \mathrm{r}}$ & $0,77 \pm 0,01^{k, a}$ & $0,65 \pm 0,01$ \\
\hline 16 & $0,84 \pm 0,01^{\mathrm{K}}$ & $0,89 \pm 0,01^{\mathrm{k}, \mathrm{r}}$ & $0,78 \pm 0,01^{k, a}$ & $0,73 \pm 0,01$ \\
\hline 17 & $0,83 \pm 0,01^{\mathrm{K}}$ & $0,91 \pm 0,01^{\mathrm{k}, \mathrm{r}}$ & $0,76 \pm 0,01^{\mathrm{k}, \mathrm{a}}$ & $0,65 \pm 0,01$ \\
\hline $12-17$ & $0,83 \pm 0,02 \mathrm{k}$ & $0,87 \pm 0,01^{\mathrm{k}, \mathrm{r}}$ & $0,77 \pm 0,01^{\kappa, a}$ & $0,66 \pm 0,01$ \\
\hline
\end{tabular}

Примітка. К, а, г-статистично значима різниця з показником груп $K, A$, г $(p<0,05)$.

Як показали дані подвійної рентгенівської абсорбціометрії, при діагностиці ожиріння у дівчаток з НАЖХП, що спирається на значення IMT, саме жировий компонент робив найбільший внесок; більше того, прогресування IMT супроводжувалося односпрямованим зростанням індексу маси жирової тканини, що підтверджує наростання маси тіла у дітей із ожирінням саме за рахунок жирового компонента (рис. 1).

Прямий кореляційний зв'язок між індексом маси жирової тканини й IMT при андроїдному ожирінні становив $\ulcorner=0,79, p<0,01$, при гіноїдному $\ulcorner=0,61, p<0,01$, між співвідношенням відсотка андроїдного і гіноїдного жиру і співвідношенням ОТ/OC - r=0,62, p<0,01. Тобто, при аналізі компонентного складу тіла дівчат пубертатного віку було встановлено, що кількість жиру андроїдної локалізації у дівчаток з НАЖХП мала пряму значиму кореляцію із загальною кількістю жирової тканини і значенням окружності талії, отже, при прогресуванні ожиріння найбільш значимо зрос- тала кількість жиру метаболічно несприятливої андроїдної локалізації, що клінічно відображалося зростанням окружності талії і співвідношення окружність талії / окружність стегон.

При вивченні продукції адипоцитокінів встановлено, що у обстежених пацієнток з НАЖХП рівень лептину перевищував аналогічний у контролі в 14,58 раза - $(64,15 \pm 1,84)$ проти $(4,40 \pm 0,11)$ нг/мл $(p<0,01)$, а адипонектину був нижчий в 1,09 раза $(6,00 \pm 0,17)$ проти $(6,51 \pm 0,16)$ мкг/мл $(p<0,03)$. Мали місце підвищені рівні АЛТ в 2,17 раза, порівняно 3 контрольними показниками, - $(32,02 \pm 0,70)$ проти $(14,77 \pm 0,28)$ Од/л $(р<0,01)$, АСТ у 1,14 раза - $(22,39 \pm$ $0,51)$ проти $(19,66 \pm 0,44)$ Од/л $(p<0,01)$, v-ГТП у 1,08 раза - $(20,07 \pm 0,44)$ проти $(18,63 \pm 0,29)$ Од/л ( $><0,01)$. У обстежених пацієнток із НАЖХП виявлені достовірні зміни показників ліпідного обміну в бік збільшення загального холестерину $((5,57 \pm 0,07)$ проти $(4,21 \pm 0,05)$ ммоль/л, $p<0,01)$, лПНЩ $((2,78 \pm$ $0,04)$ проти $(2,35 \pm 0,02)$ ммоль/л, $p<0,01)$, тригліцеридів $((1,65 \pm 0,02)$ проти $(0,85 \pm 0,01)$ мг/дл, $p<0,01)$ i

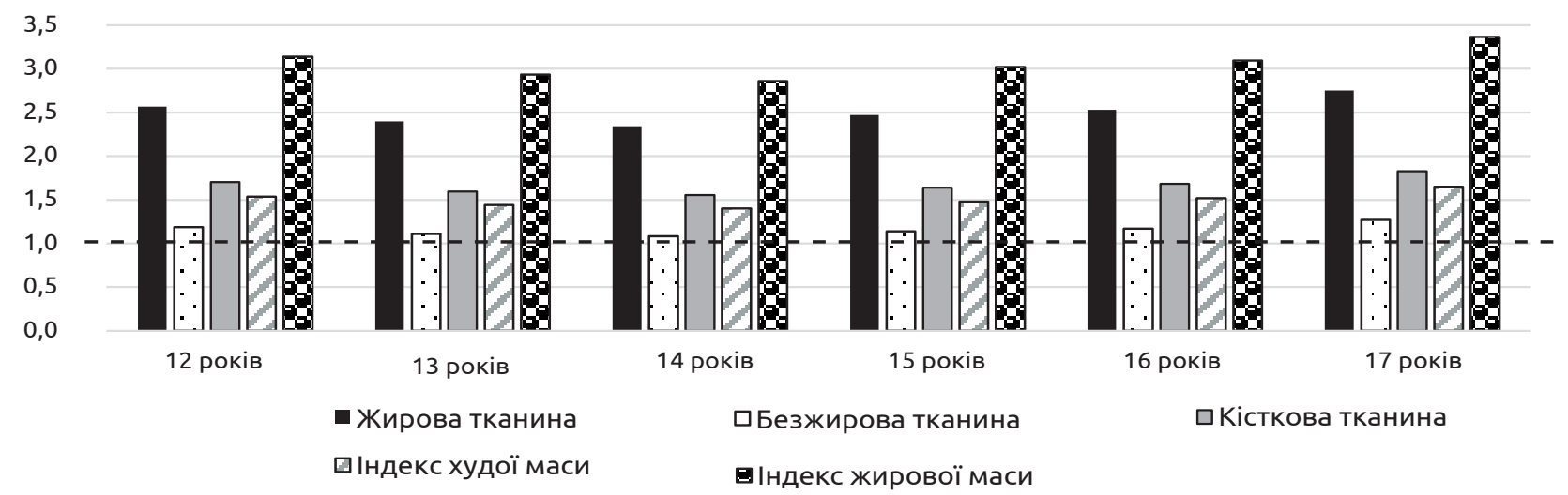

Рис. 1. Динаміка зміщення показників композиції тіла дівчаток пубертатного віку з НАЖХП відносно аналогічних показників контрольної групи за даними подвійної рентгенівської абсорбціометрії. Примітка. - - - - - Пунктиром позначено показник контрольної групи, прийнятий за одиницю. 
Огляди літератури, оригінальні дослідження, погляд на проблему, випадок з практики, короткі повідомлення зменшення ЛПВЩ $((1,11 \pm 0,01)$ проти $(2,35 \pm$ 0,02) мкмоль/л, p<0,01), що свідчило про наявність атерогенної дисліпідемії у пацієнток пубертатного віку з НАЖХП. У дівчаток з НАЖХП та ожирінням були вищі, ніж у дітей без стеатозу, рівні глюкози, у 1,25 раза $((5,64 \pm 0,05)$ проти $(4,53 \pm 0,04)$ ммоль/л, $\mathrm{p}<0,01)$, інсуліну - у 1,49 раза $((16,79 \pm 0,68)$ проти $(11,24 \pm 0,10)$ мкОд/мл, $p<0,01)$, С-пептиду - у $1,77$ раза $((4,16 \pm 0,21)$ проти $2,25 \pm 0,03)$ нг/мл, $\mathrm{p}<0,01)$,

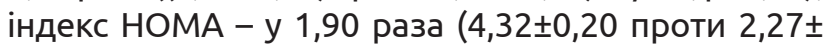
$0,03, p<0,01)$, що вказує на тісний взаємозв'язок між станом печінкового метаболізму й асоційованих з ним порушень вуглеводного обміну у дівчаток підліткового віку з ожирінням при НАЖХП. Встановлено взаємозв'язок порушень пуринового обміну зі станом печінки у хворих на НАЖХП і ожиріння. Гіперурикемію діагностовано у 69,16 \% (83) дівчаток з НАЖХП. Загалом середні рівні сечової кислоти у хворих на НАЖХП були достовірно вищими, ніж без неї, у 2,27 раза $(p<0,01)-(361,07 \pm 4,46)$ проти $(158,77 \pm 1,53)$ мкмоль/л.

Оптимальний рівень $25(\mathrm{OH})$ D у контролі спостерігали у 19,44 \% (35) випадків, в групі з НАЖХП-

рідше в 1,56 раза ( $p>0,05)$ - у 12,50 \% (15), недостатність вітаміну D - відповідно у 36,67 \% (66) проти 21,67 \% (26) пацієнток, тобто рідше в 1,69 раза ( $<<0,01)$. Характерною рисою статусу вітаміну D y дівчаток пубертатного віку з НАЖХП та ожирінням була наявність його дефіциту у 65,83 \% (79) випадків, тоді як у контролі дефіцит спостерігали рідше в 1,50 раза ( $<<0,01)$ - у 43,89 \% (79) пацієнток. У о6стежених осіб пубертатного віку не встановлено вікових відмінностей в розподілі статусу вітамінy D. Середній рівень $25(\mathrm{OH})$ D у обстежених нами дівчаток контрольної групи дорівнював $(22,00 \pm$ $0,56)$ нг/мл, тоді як у пацієнток з НАЖХП був нижчий в 1,34 раза - $(16,44 \pm 0,73)$ нг/мл $(p<0,01)$.

Дівчата з НАЖХП характеризувалися більш раннім настанням менархе - $(11,45 \pm 0,03)$ проти $(12,43 \pm 0,04)$ років у контролі, вищим балом статевого розвитку за Л. Г. Тумилович - $(10,89 \pm 0,16)$ проти $(10,27 \pm 0,18)$ балів. Більш раннє статеве дозрівання в групі дівчаток з НАЖХП і ожирінням підтверджував віковий аналіз показників формули статевого розвитку за J. М. Tanneг в динаміці пубертатного періоду (рис. 2).

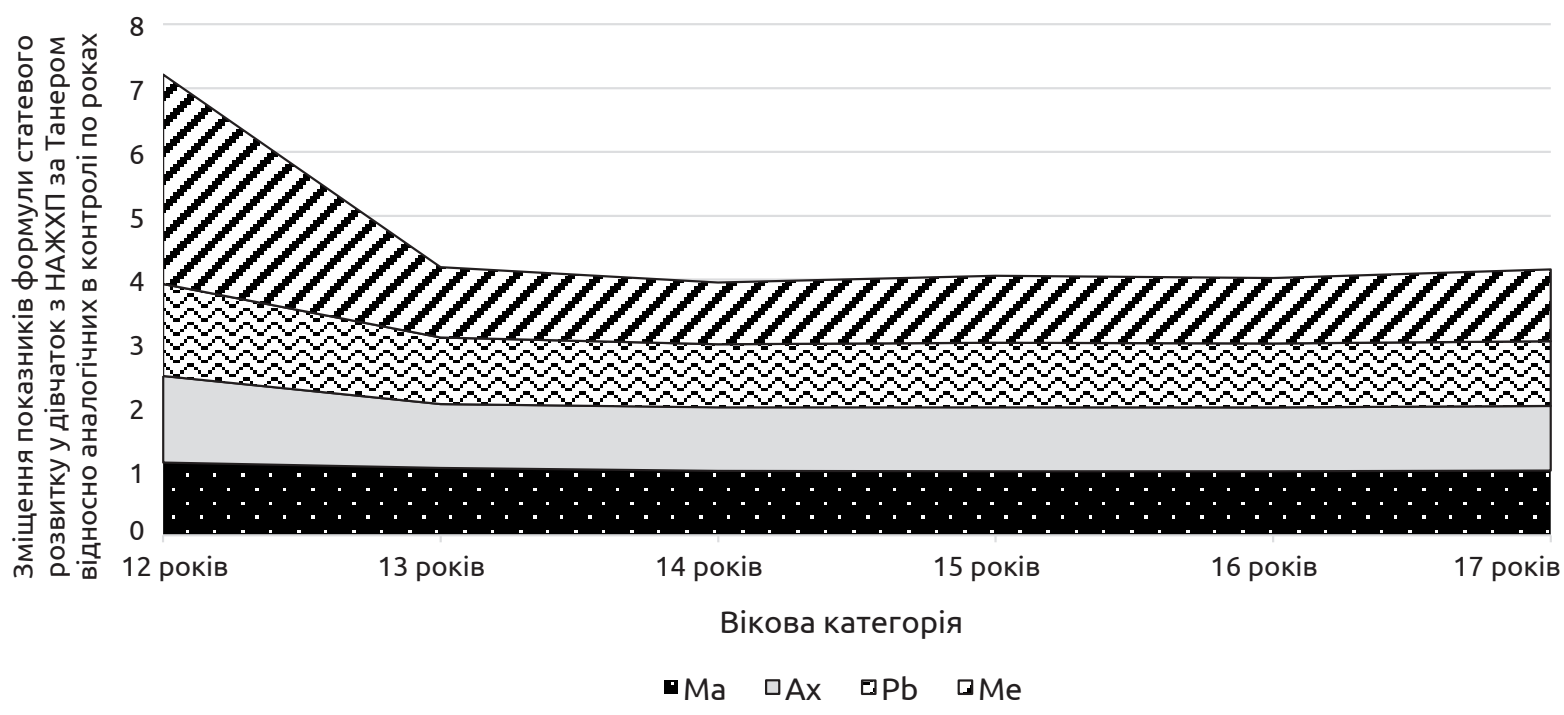

Рис. 2. Зміщення показників формули статевого розвитку у дівчаток з НАЖХП за Ј. М. Таппег відносно аналогічних показників в контролі, прийнятих за одиницю, впродовж пубертатного періоду.

Слід зазначити, що ретроспективний аналіз перебігу препубертатного періоду в обстежуваних пацієнток із НАЖХП теж мав свої особливості. Поява оволосіння на лобку, статевих губах, ріст волосся в пахвових западинах, тобто передчасне (до 7 років) і / або прискорене адренархе (до 8 років) у обстежуваних групи з НАЖХП було відзначено у 25,83 \% (31) пацієнток, що ймовірно, стало ранньою ознакою андрогенізації в дитячому віці. Інверсія вторинних статевих ознак відзначалася у 28,33 \% (34) дівчаток з НАЖХП, тоді як у групі здорових дівчаток-підлітків статеве дозрівання почи- налося з розвитку молочних залоз і в фізіологічні терміни. В контрольній групі менструації встановилися протягом року після початку менархе i були регулярними у всіх пацієнток. У дівчаток 3 НАЖХП і нездоровим морбідним ожирінням, не дивлячись на більш раннє менархе, в 62,50 \% (75) випадків розвинулася олігоменорея, у 27,50 \% (33) - аменорея, рясні менструації були у 10,00 \% (12) пацієнток, дисменорея - у 14,17 \% (17).

Висновки. Клінічний портрет дівчинки пубертатного віку з неалкогольною жировою хворобою печінки і з метаболічно нездоровим ожирінням ха- 
Огляди літератури, оригінальні дослідження, поглядн на рактеризується порушеннями ліпідного, вуглеводного, пуринового обміну, секреції адипоцитокінів, недостатністю або дефіцитом вітаміну D і більш раннім статевим дозріванням, прискореним адренархе, інвертованим пубертатом, порушеннями менструальної функції з наявністю у 62,50 \% випадків олігоменореї, у 27,50 \% - аменореї, у 10,00 \% рясних менструацій, у 14,17 \% - дисменореї.

\section{ЛІТЕРАТУРА}

1. Абатуров О. Є. Фенотипи ожиріння у дітей, клінічні прояви й генетичні асоціації / О. Є. Абатуров, А. О. Нікуліна // Здоров'я дитини. - 2020. - № 15 (4). C. 238-251.

2. Боршуляк А. А. Аспекти розвитку порушень менструальної функції в дівчат із надмірною масою тіла / А. А. Боршуляк, О. І. Боднарюк, О. А. Андрієць // Акушерство. Гинекология. Генетика. - 2017. - № 3 (3). C. 47-52.

3. Причини розвитку, діагностика та підходи до лікування стеатозу печінки та неалкогольного стеатогепатиту у дітей / В. С. Березенко, Х. 3. Михайлюк, М. Б. Диба, О. М. Ткалик // Современная педиатрия. 2014. - № 4 (60). - C. 119-125.

4. Asrih M. Metabolic syndrome and nonalcoholic fatty liver disease: is insulin resistance the link? / M. Asrih, F. R. Jornayvaz // Mol. Cell Endocrinol. - 2015. - Vol. 418 (Pt 1). - P. 55-65.

5. Cardiovascular risk factors, nonalcoholic fatty liver disease, and carotid artery intima-media thickness in an adolescent population in southern Italy / C. A. Caserta, G. M. Pendino, A. Amante [et al.] // Am. J. Epidemiol. 2010. - Vol. 171. - P. 1195-1202.

6. D'Adamo E. Metabolic syndrome in pediatrics: old concepts revised, new concepts discussed / E. D'Adamo, N. Santoro, S. Caprio // Curr. Probl. Pediatr. Adolesc. Health Care. - 2013. - Vol. 43. - P. 114-123.

7. Mencin A. A. Nonalcoholic fatty liver disease in children / A. A. Mencin, J. E. Lavine // Curr. Opin. Clin. Nutr. Metab. Care. - 2011. - Vol. 14. - P. 151-157.

8. Nonalcoholic fatty liver disease - a multisystem disease? / Mikolasevic I., Milic S., Turk Wensveen T., et al. // World J. Gastroenterol. - 2016. - Vol. 22. - P. 9488-9505.

9. Nonalcoholic fatty liver disease in children / J. P. Mann, L. Valenti, E. Scorletti [et al.] // Semin. Liver Dis. - 2018. - Vol. 38. - P. 1-13.

\section{REFERENCES}

1. Abaturov, O.Ye., \& Nikulina, A.O. (2020). Fenotypy ozhyrinnia u ditei, klinichni proiavy y henetychni asotsiatsii [Phenotypes of obesity in children, clinical manifestations and genetic associations]. Zdorovia dytyny - Child's Health, 15(4),238-251.DOI:10.22141/2224-0551.15.4.2020.208476 [in Ukrainian].

2. Borshuliak, A.A., Bodnariuk, O.I., \& Andriiets, O.A. (2017). Aspekty rozvytku porushen menstrualnoi funktsii v divchat yiz nadmirnoiu masoiu tila [Aspects of the development of menstrual disorders in overweight girls]. Akusherstvo. Hynekolohyia. Henetyka - Obstetrics. Gynecology. Genetics, 3 (3), 47-52 [in Ukrainian].
10. Nonalcoholic fatty liver disease in children: hepatic and extrahepatic complications / P. K. C. Selvakumar, M. N. Kabbany, V. Nobili, N. Alkhouri // Pediatr. Clin. North Am. - 2017. - Vol. 64. - P. 659-75.

11. Nonalcoholic fatty liver disease, liver fibrosis, and cardiometabolic risk factors in adolescence: a cross-sectional study of 1874 general population adolescents / D. A. Lawlor, M. Callaway, C. Macdonald-Wallis [et al.] // J. Clin. Endocrinol. Metab. - 2014. - Vol. 99 (3). - P. 410-417.

12. Nonalcoholic fatty liver disease: a precursor of the metabolic syndrome / A. Lonardo, S. Ballestri, G. Marchesini [et al.] // Dig. Liver Dis. - 2015. - Vol. 47. - P. 181-190.

13. Novel insights in the metabolic syndrome in childhood and adolescence / S. Bussler, M. Penke, G. Flemming [et al.] // Horm. Res. Paediatr. - 2017. - Vol. 88. P. 181-193.

14. Portal inflammation is independently associated with fibrosis and metabolic syndrome in pediatric nonalcoholic fatty liver disease / J. P. Mann, R. De Vito, A. Mosca [et al.] // Hepatology. - 2016. - Vol. 63 (3). - P. 745-753.

15. Prevalence of fatty liver in children and adolescents / J. B. Schwimmer, R. Deutsch, T. Kahen [et al.] // Pediatrics. - 2006. - Vol. 118. - P. 1388-1393.

16. Prevalence of Nonalcoholic Fatty Liver Disease in Children with Obesity / E. L. Yu, S. Golshan, K. E. Harlow [et al.] // J. Pediatr. - 2019. - Vol. 207. - P. 64-70.

17. Prevalence of nonalcoholic fatty liver disease in children with obesity / E. L. Yu, S. Golshan, K. E. Harlow [et al.] // J. Pediatr. - 2018. - Vol. 207. - P. 64-70.

18. Reaven G. M. Banting Lecture Role of insulin resistance in human disease / G. M. Reaven // Diabetes. - 1988. Vol. 37. - P. 1595-1607.

19. The prevalence of non-alcoholic fatty liver disease in children and adolescents: a systematic review and metaanalysis / E. L. Anderson, L. D. Howe, H. E. Jones [et al.] // PLOS ONE. - 2015. - Vol. 10 (10). - e0140908.

3. Berezenko, V.S., Mykhailiuk, Kh.Z., Dyba, M.B., \& Tkalyk, O.M. (2014). Prychyny rozvytku, diahnostyka ta pidkhody do likuvannia steatozu pechinky ta nealkoholnoho steatohepatytu u ditei [Causes, diagnosis and approaches to the treatment of hepatic steatosis and non-alcoholic steatohepatitis in children]. Sovremennaya pediatriya - Modern Pediatrics, 4 (60),119-125 [in Ukrainian].

4. Asrih, M., \& Jornayvaz, F.R. (2015). Metabolic syndrome and nonalcoholic fatty liver disease: is insulin resistance the link? Mol. Cell. Endocrinol., 418 (Pt 1), 55-65. DOI: 10.1016/j.mce.2015.02.018. 
Огляди літератури, оригінальні дослідження, погляд на проблему, випадок з практики, короткі повідомлення

5. Caserta, C.A., Pendino, G.M., Amante, A., Vacalebre, C., Fiorillo, M.T., Surace, P., ..., \& Marcucci, F. (2010). Cardiovascular risk factors, nonalcoholic fatty liver disease, and carotid artery intima-media thickness in an adolescent population in southern Italy. Am. J. Epidemiol., 171, 1195-1202. DOI: 10.1093/aje/kwq073.

6. D'Adamo, E., Santoro, N., \& Caprio, S. (2013). Metabolic syndrome in pediatrics: old concepts revised, new concepts discussed. Curr. Probl. Pediatr. Adolesc. Health Care., 43, 114-123. DOI: 10.1016/j.cppeds.2013.02.004.

7. Mencin, A.A., \& Lavine, J.E. (2011). Nonalcoholic fatty liver disease in children. Curr. Opin. Clin. Nutr. Metab. Care., 14, 151-157. DOI: 10.1097/MCO.0b013e328342baec.

8. Mikolasevic, I., Milic, S., Turk Wensveen, T., Grgic, I., Jakopcic, I., Stimac, D., ..., \& Orlic, L. (2016). Nonalcoholic fatty liver disease - a multisystem disease? World J. Gastroenterol., 22, 9488-9505. DOI: 10.3748/wjg.v22.i43.9488.

9. Mann, J.P., Valenti, L., Scorletti, E., Byrne, C.D., \& Nobili, V. (2018). Nonalcoholic fatty liver disease in children.SeminLiverDis., 38,1-13.DOI:10.1055/s-0038-1627456.

10. Selvakumar, P.K.C., Kabbany, M.N., Nobili, V., \& Alkhouri, N. (2017). Nonalcoholic fatty liver disease in children: hepatic and extrahepatic complications. Pediatr. Clin. North. Am., 64, 659-675. DOI: 10.1016/j.pcl.2017.01.008.

11. Lawlor, D.A., Callaway, M., Macdonald-Wallis, C., Anderson, E., Fraser, A., Howe, L.D., ..., \& Sattar, N. (2014). Nonalcoholic fatty liver disease, liver fibrosis, and cardiometabolic risk factors in adolescence: a cross-sectional study of 1874 general population adolescents. J. Clin. Endocrinol. Metab., 99 (3), E410-417. DOI: 10.1210/jc.2013-3612.

12. Lonardo, A., Ballestri, S., Marchesini, G., Angulo, P., \& Loria, P. (2015). Nonalcoholic fatty liver disease: a precursor of the metabolic syndrome. Dig. Liver Dis., 47, 181-190. DOI: 10.1016/j.dld.2014.09.020.

13. Bussler, S., Penke, M., Flemming, G., Elhassan, Y.S., Kratzsch, J., Sergeyev, E., ..., \& Kiess, W. (2017). Novel insights in the metabolic syndrome in childhood and adolescence. Horm. Res. Paediatr., 88, 181-193. DOI: 10.1159/ 000479510.

14. Mann, J.P., De Vito, R., Mosca, A., Alisi, A., Armstrong, M.J., Raponi, M., ..., \& Nobili, V. (2016). Portal inflammation is independently associated with fibrosis and metabolic syndrome in pediatric nonalcoholic fatty liver disease. Hepatology, 63 (3), 745-753. DOI: 10.1002/hep.28374

15. Schwimmer, J.B., Deutsch, R., Kahen, T., Lavine, J.E., Stanley, C., \& Behling, C. (2006). Prevalence of fatty liver in children and adolescents. Pediatrics, 118, 1388-1393. DOI: 10.1542/peds.2006-1212.

16. Yu, E.L., Golshan, S., Harlow, K.E., Angeles, J.E., Durelle, J., Goyal, N.P., ..., \& Schwimmer, J.B. (2019). Prevalence of nonalcoholic fatty liver disease in children with obesity. J. Pediatr., 207, 64-70. DOI: 10.1016/j.jpeds.2018.11.021.

17. Yu, E.L., Golshan, S., Harlow, K.E., Angeles, J.E., Durelle, J., Goyal, N.P., ..., \& Schwimmer, J.B. (2018). Prevalence of nonalcoholic fatty liver disease in children with obesity. J. Pediatr., 207, 64-70. DOI: 10.1016/j.jpeds.2018.11.021.

18. Reaven, G.M. (1988). Banting Lecture Role of insulin resistance in human disease. Diabetes, 37, 1595-1607.

19. Anderson, E.L., Howe, L.D., Jones, H.E., Higgins, J.P., Lawlor, D.A., \& Fraser, A. (2015). The prevalence of non-alcoholic fatty liver disease in children and adolescents: a systematic review and meta-analysis. PLOS ONE, 10 (10), e0140908. DOI: 10:e0140908.10.1371/journal. pone.0140908.

\title{
КЛИНИЧЕСКИЙ ПОРТРЕТ ДЕВОЧКИ ПУБЕРТАТНОГО ВОЗРАСТА С НЕАЛКОГОЛЬНОЙ ЖИРОВОЙ БОЛЕЗНЬЮ ПЕЧЕНИ И МЕТАБОЛИЧЕСКИ НЕЗДОРОВЫМ ОЖИРЕНИЕМ
}

๑Е. Ф. Чайковская

\author{
Львовский национальный медицинский университет имени Данила Галицкого
}

PEзЮМЕ. В Украине 10 \% детского населения имеет избыточную массу тела. Одним из современных актуальных вопросов пубертатного периода у девушек с ожирением являются диффузные заболевания печени, из которых неалкогольная жировая болезнь печени (НАЖБП) становится одной из наиболее частых проблем со здоровьем.

Цель - изучение особенностей клинико-метаболических показателей и полового развития девочек пубертатного возраста с НАЖБП и метаболически нездоровым ожирением.

Материал и методы. Под наблюдением находились 120 девушек в возрасте 12-17 лет с НАЖБП и метаболически нездоровым ожирением, а также 180 условно соматически здоровых девушек с нормальным половым развитием и нормальной массой тела. Изучены антропометрические показатели, параметры ферментного, липидного, углеводного, пуринового обмена, секреция адипоцитокинов, 25(OH)D, оценено половое развитие.

Результаты. Для девочек пубертатного возраста с НАЖБП и ожирением были наиболее характерны увеличение индекса массы тела в 2,80 раза ( $<<0,01)$, в основном за счет увеличения индекса жировой ткани в 3,07 раза $(p<0,01)$, соотношения окружности талии / окружности бедер в 1,26 раза ( $<<0,01)$. Уровень лептина достоверно превышал аналогичный в контроле в 14,58 раза, АЛт - в 2,17, уровень глюкозы- в 1,25, С-пептида - в 1,77, индекс HOMА - в 1,90, мочевой кислоты - в 2,27, а уровень 25(ОН)D был снижен в 1,34 раза (р<0,01). Девушки с НАЖБП характеризовались более ранним наступлением менархе - $(11,45 \pm 0,03)$ против $(12,43 \pm 0,04)$ лет в контроле, более высоким баллом полового развития по Л. Г. Тумилович - $(10,89 \pm 0,16)$ против $(10,27 \pm 0,18)$ баллов, нарушениями менструальной функции с наличием в 62,50 \% случаев олигоменореи, в 27,50 \% - аменореи, в 10,00 \% - обильных менструаций, в 14,17 \% - дисменореи. 
Огляди літератури, оригінальні дослідження, погляд на проблему, випадок з практики, короткі повідомлення

Выводы. Клинический портрет девочки пубертатного возраста с НАЖБП и с метаболически нездоровым ожирением характеризуется нарушениями липидного, углеводного, пуринового обмена, секреции адипоцитокинов, недостаточностью или дефицитом витамина D и более ранним половым созреванием, ускоренным адренархе, инвертированным пубертатом, нарушениями становления менструальной функции.

КЛЮЧЕВЫЕ СЛОВА: ожирение; неалкогольная жировая болезнь печени; композиция тела; метаболический синдром; ферменты печени; липидный обмен; углеводный обмен; пуриновый обмен; 25(ОН)D; половое развитие.

\title{
CLINICAL PORTRAIT OF A PUBERTY GIRL WITH NON-ALCOHOLIC FAT LIVER DISEASE AND METABOLIC UNHEALTHY OBESITY
}

\author{
@E. F. Chaikivska
}

\section{Danylo Halytsky Lviv National Medical University}

SUMMARY. In Ukraine, $10 \%$ of the child population is overweight. One of the current topical issues of puberty in obese girls is diffuse liver disease, of which non-alcoholic fatty liver disease (NAFLD) is becoming one of the most common health problems.

The aim - to study the characteristics of clinical and metabolic parameters and sexual development in adolescent girls with NAFLD and metabolically unhealthy obesity.

Material and Methods. The study included 120 girls aged 12-17 years with NAFLD and metabolically unhealthy obesity, as well as 180 conditionally healthy girls with normal sexual development and normal body weight. Anthropometric indicators, parameters of enzyme, lipid, carbohydrate, purine metabolism, secretion of adipocytokines, 25 (OH) D were studied, sexual development was assessed.

Results. For girls of puberty with NAFLD and obesity, the following were most characteristic: an increase in body mass index by 2.80 times $(p<0.01)$, mainly due to an increase in adipose tissue index by 3.07 times $(p<0.01)$, the ratio waist/hip circumference 1.26 times $(p<0.01)$. The level of leptin significantly exceeded that in the control by 14.58 times, ALT - 2.17, glucose - 1.25, C-peptide - 1.77, HOMA index - 1.90, uric acid - 2.27, and the level of $25(\mathrm{OH}) \mathrm{D}$ was reduced by 1.34 times $(p<0.01)$. Girls with NAFLD were characterized by an earlier onset of menarche $-(11.45 \pm 0.03)$ versus $(12.43 \pm 0.04)$ years in the control, a higher score for sexual development according to L. G. Tumilovich $-(10.89 \pm 0.16)$ versus $(10.27 \pm 0.18)$ points, menstrual dysfunction with the presence of oligomenorrhea in $62.50 \%$ of cases, amenorrhea - in $27.50 \%$, heavy menstruation - in $10.00 \%$, dysmenorrhea - in $14.17 \%$.

Conclusions. The clinical portrait of a pubertal girl with NAFLD and metabolically unhealthy obesity is characterized by impaired lipid, carbohydrate, purine metabolism, secretion of adicytopokinids, vitamin D deficiency or deficiency and earlier puberty, accelerated adrenarche, inverted puberty, and impaired menstrual function.

KEY WORDS: obesity; non-alcoholic fatty liver disease; body composition; metabolic syndrome; liver enzymes; lipid metabolism; carbohydrate metabolism; purine metabolism; $25(\mathrm{OH}) \mathrm{D}$; sexual development. 